\title{
Letters
}

\section{Don't use an instrument of oppression as a symbol of diversity and inclusion}

This article has been retracted by CMAJ. For more information, see http://www.cmaj.ca/lookup/cmaj.212121

\section{Sherif Emil MDCM}

Director, Harvey E. Beardmore Division of Pediatric Surgery; professor of pediatric surgery, Surgery and Pediatrics, The Montreal Children's Hospital; McGill University Health Centre; McGill University Faculty of Medicine, Montréal, Que.

Cite as: CMAJ 2021 December 20;193: E1923. doi: 10.1503/cmaj.80742

Competing interests: None declared.

Content licence: This is an Open Access article distributed in accordance with the terms of the Creative Commons Attribution (CC BY-NC-ND 4.0) licence, which permits use, distribution and reproduction in any medium, provided that the original publication is prop-erly cited, the use is noncommercial (i.e., research or educational use), and no modifica-tions or adaptations are made. See: https:// creativecommons.org/licenses/by-nc-nd/4.0/ 